\title{
0256 LAUNCHING AN INDUSTRY LED COALITION FOR SAFETY AND HEALTH OF AGRICULTURAL WORKERS
}

B C Lee*, R M Fisher, D J Murphy* Correspondence: National Farm Medicine Center, 1000 North Oak Avenue Marshfield, WI 54449, USA

10.1136/ip.2010.029215.256

Agriculture is the most dangerous industry in the United States with an estimated annual 650 deaths, 90000 injuries, and a death rate eight times greater than the all-industry average. Based on successes in Australia and Canada, we aimed to change this trend by having leaders within agricultural businesses and farm organisations become a unified voice for national agricultural safety initiatives. Beginning in 2006, we convened in-person meetings building momentum that launched the Agricultural Safety and Health Council of America (ASHCA) in late 2007. A compelling feature of this new organization was leadership dominated by people with authority to introduce safety measures within their respective agricultural networks. ASHCA leaders drafted a mission, governance structure, bylaws, and then identified strategic initiatives. ASHCAs Strategic Plan has priorities of: (a) promoting communications and partnerships; (b) promoting evidence-based best practices; (c) engaging with National Institute for Occupational Safety and Health (NIOSH) funded agricultural safety and health researchers and (d) guiding the research agenda of federal agencies, including NIOSH and US Department of Agriculture. Now 2 years later ASHCA has grown to encompass 30 organisations. In January 2010, ASHCA hosted a first of its kind national conference, Be Safe, Be Profitable: Protecting Workers in Agriculture, uniting agricultural leaders, safety practitioners, researchers and farm workers in determining the best safety practices for workers in agriculture. Proceedings from this groundbreaking conference will be published in a dedicated issue of the Journal of Agromedicine July 2010 and used as a reference for agricultural producers and safety professionals. 